\title{
Uma discussão sobre a possibilidade da criação institucional e sinergia entre Estado e sociedade: o caso do P1MC no Semiárido brasileiro
}

JACKELINE AMANTINO DE ANDRADE

Universidade Federal de Pernambuco / Departamento de Ciências Administrativas, Programa de Pós-Graduação EM AdMINISTRAÇÃO, RECIFE - PE, BRASIL

JosÉ RAIMUNDO CORDEIRO NETO

Universidade Federal do Vale do São Francisco / Colegiado de AdMinistração, Petrolina - PE, Brasil

\begin{abstract}
Resumo
Este artigo analisa a criação institucional no processo de políticas públicas com base no conceito de sinergia definido por Evans (1996). Para tanto, é examinado um estudo de caso relativo ao Programa Um Milhão de Cisternas Rurais (P1MC), desenvolvido no campo das políticas hídricas no Semiárido brasileiro. Trata-se de uma pesquisa qualitativa cujo foco foi o Vale do São Francisco e que envolveu um conjunto de organizações da sociedade civil e públicas localizadas na microrregião de Juazeiro-BA. Além de dados documentais, a investigação contemplou a coleta e análise de dados oriundos de entrevistas. Observou-se um histórico de relações sociais pouco propensas à criação imaginativa de arranjos institucionais que facilitassem as interações sinérgicas Estado-sociedade naquele contexto, apesar do empoderamento e acúmulo de capital social ao longo de anos terem possibilitado algumas transformações e empreendimentos coletivos das comunidades estudadas.
\end{abstract}

Palavras-chave: Políticas públicas. Relações Estado-sociedade. Neoinstitucionalismo político. Criação institucional. Sinergia.

A discussion about the possibility of institutional creation and synergy between State and society: the case of P1MC in the brazilian Semiarid region

\begin{abstract}
This article analyzes institutional creation in the public policy process by having the concept of synergy as defined by Evans (1996) as a basis. To do this, we examine a case study related to the One Million Rural Cisterns Program (P1MC), conducted in the field of water policies in the Brazilian Semiarid region. This is a qualitative research focused on Vale do São Francisco and it gathered a set of civil society and public organizations located in the microregion of Juazeiro, Bahia, Brazil. In addition to documentary data, the investigation addressed the collection and analysis of data obtained through interviews. We observed a history of social relations unlikely to provide imaginative creation of institutional arrangements that could facilitate synergistic State-society interactions in that context, although empowerment and social capital accumulation over the years have enabled some transformations and collective enterprises in the communities under study.
\end{abstract}

Keywords: Public policies. State-society relations. Political neoinstitutionalism. Institutional creation. Synergy.

\section{Una discusión sobre la posibilidad de creación institucional y sinergia entre Estado y sociedad: el caso del P1MC en el Semiárido brasileño}

\section{Resumen}

Este artículo analiza la creación institucional en el proceso de políticas públicas con base en el concepto de sinergia definido por Evans (1996). Para esto, se examina un estudio de caso relativo al Programa Un Millón de Cisternas Rurales (P1MC), desarrollado en el ámbito de las políticas hídricas en el Semiárido brasileño. Se trata de una investigación cualitativa cuyo foco fue el Vale do São Francisco y que involucró una serie de organizaciones de la sociedad civil y públicas situadas en la micro-región de Juazeiro, Bahía, Brasil. Además de datos documentales, la investigación incluyó la recogida y el análisis de datos derivados de entrevistas. Se observó una historia de relaciones sociales poco propensas a la creación imaginativa de arreglos institucionales que facilitaran las interacciones sinérgicas Estado-sociedad en aquel contexto, a pesar del empoderamiento y la acumulación de capital social a lo largo de los años posibilitaran algunos cambios y desarrollos de las comunidades estudiadas.

Palabras clave: Políticas públicas. Relaciones Estado-sociedad. Neo-institucionalismo político. Creación institucional. Sinergia. 


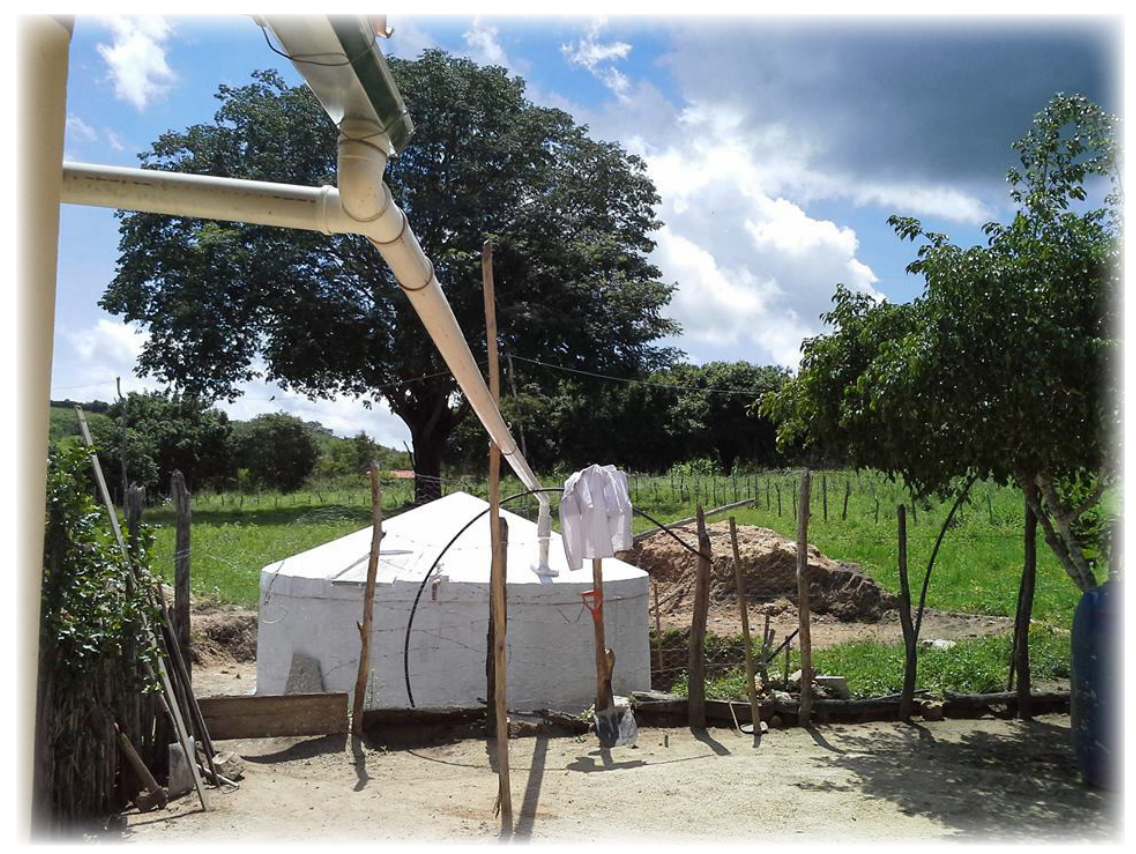

\section{INTRODUÇÃO}

Ao introduzir a sua proposição de análise política, Laswell (1958) tinha a intenção de examinar cientificamente aquilo que os governos faziam empiricamente, isto é, políticas públicas, e, também, de responder as seguintes questões: quem ganha o que, por que, e que diferença isso faz. No entanto, foi a definição de Easton (1965) - baseada na abordagem de sistemas - que se propagou até os dias de hoje. A política pública é um output daquilo que partidos, grupos de interesse e a mídia introduzem no processamento do sistema político, cabendo aos governos executá-la por meio das conhecidas etapas de formulação, implementação e avaliação, expressas em programas e projetos governamentais (SOUZA, 2006).

Sob o escopo da ciência política, questionamentos a respeito de quem ganha o que, por que, e que diferença isso faz encontraram inicialmente resposta em modelos como o pluralismo. Segundo tal modelo, a ação do Estado é um reflexo das pressões de grupos de interesse, indicando "quem governa" (DAHL, 1970) pelos outputs produzidos. Já nos modelos corporativista e marxista, também conhecidos como elitistas, o último aponta que o Estado opta exclusivamente por políticas orientadas por aqueles que estão no poder, enquanto o primeiro considera a composição dessas políticas baseando-se nos interesses do triângulo de ferro, isto é, a união da tecnocracia estatal com elites empresariais e as representações dos partidos políticos no legislativo.

Deve-se considerar, no entanto, que a diversificação e a complexificação do processo político nas últimas décadas conduziram os estudos sobre políticas públicas a significativas reformulações (FARIA, 2003). Houve, até mesmo, necessidade de resgate da importância atribuída originalmente por Harold Laswell à diversidade do conhecimento implicada no processo político e nas políticas públicas. Assim, conforme Faria (2003, p. 22), é necessário distinguir "[...] os modelos analíticos nos quais o conhecimento é endógeno ao policy process e aqueles nos quais ele nada mais é do que input à caixa preta eastoniana".

Crítico da dicotomia entre política e administração originalmente concebida por Woodrow Wilson no final do século XIX, Laswell buscou focar as contribuições e interações entre diferentes atores e instituições no processo político com base em

\footnotetext{
* Fonte da imagem: José Raimundo Cordeiro Neto (co-autor).
} 
um modelo de etapas (JANN e WEGRICH, 2007). Esta dimensão processual foi, no entanto, apropriada pela escolha racional sob contornos mais prescritivos. Retomou-se a distinção entre política e administração e, numa combinação com o modelo eastoniano de inputs e outputs, foi definido o conhecido modelo dos ciclos de políticas com a intenção de vincular o processo decisório à implementação.

Desse modo, no ciclo da política, uma vez que um problema adentra a agenda pública, é apropriado pelo Estado e segue a sequência lógica da formulação, implementação e avaliação, ao mesmo tempo em que se torna matéria da ação dos governos e dos políticos fortemente vinculada ao ciclo político e decisório destes últimos, apesar da possibilidade de influência de outros atores. Entretanto, esse incremento sequencial é questionado à medida que se evidenciam os contínuos enredamentos e encaixes das etapas ao longo do processo (JANN e WEGRICH, 2007) e a ênfase no processo decisório se desloca para o entendimento da multiplicidade de atores e ações envolvidos, dada a sua complexidade por conta do contexto da globalização (FARIA, 2003).

Para Evans (1993, p. 2), mais do que tudo, trata-se de uma mudança analítica em que se deixa de lado a caixa preta eastoniana e se passa a uma análise minuciosa, "[...] não apenas no sentido da perícia e perspicácia dos tecnocratas no interior do aparelho de Estado, mas também no sentido de uma estrutura institucional que seja durável e efetiva", em especial, nas suas relações com "estruturas sociais circundantes". Além da análise da burocracia, da pluralidade de interesses políticos, também são considerados conhecimentos, práticas, visões de mundo em suas particularidades e que orientam a performance das políticas públicas (EVANS, 1995).

Assim, a dinâmica das políticas públicas não pode estar limitada ao incremento de etapas sequenciais atribuídas ao processo político e à ação governamental, é necessário considerar, também, a dinâmica institucional que é sensível ao ambiente circundante na medida em que políticas públicas não são simples reflexo de inputs e outputs do sistema político. Ou seja, para a análise política é necessário compreender a dinâmica das relações entre Estado e sociedade e discutir como formatos institucionais, cultura política e ação cívica podem produzir efeitos no desempenho de políticas públicas.

Dessa perspectiva, o objetivo neste artigo é discutir a análise de políticas públicas considerando a criação endógena de novos arranjos institucionais e de sua capacidade de gerar sinergia entre Estado e sociedade e possibilitar mudanças institucionais. Para tanto é abordado o caso do Programa Um Milhão de Cisternas (P1MC), que trata de política direcionada aos problemas de recursos hídricos e convivência no Semiárido brasileiro. Assim, analisa-se em que medida a criação institucional, propiciada pelo acúmulo de capital social e empoderamento da população rural pobre sertaneja, permitiu o desenvolvimento das capacidades governativas dessa política por meio de sinergia institucional entre Estado e sociedade.

Além desta introdução, esse artigo constitui-se de mais quatro seções. A próxima seção apresenta o referencial conceitual que trata da criação institucional, destacando a proposição de Evans $(1993 ; 1995 ; 1996)$ sobre a sinergia nas relações Estado e sociedade. Logo em seguida são apresentados os procedimentos metodológicos adotados no desenvolvimento do estudo de caso que constitui a base empírica de análise deste artigo. Na quarta seção são analisados os resultados, considerando a dinâmica de relações Estado e sociedade no contexto do Semiárido brasileiro, a criação institucional que propiciou a emergência do P1MC e os limites para a constituição de relações sinérgicas. Na última seção são apresentadas as considerações finais relativas aos achados, com a discussão de suas implicações na dinâmica de relação Estado e sociedade e no desenvolvimento de políticas públicas.

\section{POLÍTICAS PÚBLICAS: EM DIREÇÃo À SINERGIA E À CRIAÇÃO INSTITUCIONAL?}

Tradicionalmente, a análise de políticas públicas tem se baseado numa compreensão atomizada dos sujeitos e coletividades que é inerente ao individualismo metodológico. Se, em termos éticos, há uma sobressocialização de indivíduos face às normas exaradas pelo Estado pertinente à concepção funcionalista-sistêmica, por outro lado, o Estado em ação, traduzido na centralidade dos governos, é compreendido sob os pressupostos da escolha racional em uma perspectiva subsocializada herdeira do neoclassicismo econômico. 
Granovetter (2009) critica essas atomizações, o utilitarismo orientado ao interesse próprio de acordo com a ótica subsocializada econômica, como também os padrões de comportamento interiorizados oriundos da supersocialização difundida pelo funcionalismo sociológico. Para ele essas versões convergem no isolamento de atores do contexto social, algo também presente no Leviatã, de Thomas Hobbes, no qual o problema da ordem social se traduz em:

[...] infelizes representantes do "estado de natureza", oprimidos pela desordem resultante de sua atomização, renunciam alegremente a todos os seus direitos em nome de um poder autoritário e, subsequentemente, se comportam de maneira pacata e honrada; pelo artifício de um contrato social, passando então diretamente de um estado subsocializado para um supersocializado. (GRANOVETTER, 2009, p. 38).

A ordem instituída é, no entanto, um processo permeado pela dinâmica à medida que o legado institucional (path dependence) é impactado pelo desenvolvimento histórico, como indica o neoinstitucionalismo político. Isso, no entanto, não significa que se possam eleger opções e romper com o instituído tão automaticamente como sugere a escolha racional utilitarista, pois, de acordo com Jepperson (1991), as instituições são simultaneamente controle e empoderamento.

Assim, se as escolhas passadas contam para (ou determinam) as variações das sequências sociopoliticas - isto é, o conceito de path dependence (KATO, 1996) -, essa dependência de caminho também significa que, ao iniciar uma trilha, sempre existirá custo para revertê-la, segundo o entendimento de que escolhas de ação são muito mais situacionais do que dependentes de cálculo instrumental (LEVI, 1996).

Putnam (1996), por exemplo, analisa historicamente reformas institucionais, considerando diferentes regiões da Itália e identifica desempenhos institucionais desiguais entre o norte e o sul do país, os quais vincula às diferenças na performance cívica das comunidades. Ao salientar a relação entre civismo e desenvolvimento institucional, ele indica que a confiança é um elemento fundamental para o «problema da ordem» - esta se orienta pela reciprocidade à medida que a conciliação entre interesses individuais e solidariedade diminui custos de transação. Por sua vez, a participação cívica eleva o custo do comportamento oportunista, ao mesmo tempo que facilita o fluxo de informações, reforçando a reciprocidade e a cooperação. Porém, mesmo destacando a importância do capital social para o desenvolvimento econômico-social, Putnam não apresenta uma saída para a dependência de caminho (path dependence) daquelas comunidades que apresentam deficits de civismo.

Dessa perspectiva, "[...] o capital social pode ser usado para promover ou para minar o bem público" (WOOLCOCK e NARAYAN, 2000 , p. 226). Segundo esses autores, ao tratar o capital social como uma variável dependente, o institucionalismo político acaba por reforçar uma visão sobressocializada, uma vez que a capacidade de ação de grupos sociais direcionada ao interesse coletivo depende da qualidade das instituições formais já existentes que podem abriga-la. Todavia se deve considerar que, ao longo do trajeto, existirão outros pontos de escolha e, mesmo diante de limitações para a reversão (LEVI, 1996), seria possível incorporar aprendizado e capacidades para fazer de outro modo (GIDDENS, 1981).

Côrtes (2009, p. 26) sugere que, juntamente com a primazia das instituições, é necessário buscar "[...] uma resposta sobre como os atores políticos tornam-se agentes e empreendem mudanças" e, com isso, evitar que a imersão em contextos institucionais constitua-se numa prisão de trajetórias políticas. Ao mesmo tempo, Woolcock e Narayan (2000) propõem a sinergia entre Estado e sociedade, vislumbrando a possibilidade de criação institucional por meio da heterogeneidade institucional e da combinação top-down e bottom-up na implementação de políticas.

Wookcock e Narayan (2000) estão orientados pelo conceito de autonomia inserida, uma vez que "[...] as conexões com a sociedade civil se tornam parte da solução em vez de parte do problema", constituindo-se num "[...] projeto partilhado por um aparelho burocrático altamente desenvolvido e um conjunto relativamente organizado de atores privados que [pode] fornecer informações úteis e implementação descentralizada" (EVANS, 1993, p. 30). Autonomia inserida ou imersa implica uma aproximação da burocracia com a sociedade por intermédio de "[...] um conjunto de ligações sociais que unem o Estado à sociedade, provendo canais institucionais para a contínua negociação e renegociação de objetivos e políticas" (EVANS, 1995, p. 12).

No caso brasileiro, deve-se ressaltar que essa inserção seria vinculada aos pressupostos participativos e de descentralização presentes nas políticas públicas a partir da Constituição de 1988. Entre outros dispositivos, este marco legal instituiu uma série de mecanismos para o envolvimento de diversos atores na formulação e na gestão das políticas públicas, tornando o ambiente institucional mais complexo em virtude da necessidade de serem criados novos arranjos institucionais em sua 
coordenação (GOMIDE e PIRES, 2014). Assim, não se confunde a autonomia inserida com anéis burocráticos ${ }^{1}$, sendo ela caracterizada como contraponto ao insulamento burocrático, mecanismo corporativo desenvolvido para resguardar setores estratégicos do Estado desenvolvimentista brasileiro da captura de práticas clientelistas no século passado (NUNES, 2003).

Para Evans (1993), a autonomia inserida incentivaria a adoção de metas coletivas necessárias para que se produzisse sinergia institucional e viabilizaria transformações sociopolíticas e econômicas. A sinergia institucional distingue-se, portanto, da coprodução de bens e serviços que é definida como aquilo que o governo faz e os cidadãos realizam, conforme sugerido por Ostrom (1996).

Evans (1996) propõe ir mais além, isto é, aos fundamentos microinstitucionais das relações Estado e sociedade. Para ele, a coprodução é uma complementaridade na medida em que Estado e sociedade se apoiam mutuamente por meio de uma divisão de trabalho consciente e típica da separação entre funções públicas e privadas e é convencionalmente adotada em inter-relações tipo parcerias público-privado. Já fortes conexões entre agências estatais e organizações estritamente enraizadas na sociedade civil são os elementos constitutivos daquilo que Evans (1996) concebe como inserção autônoma.

A complementaridade vinculada à imersão, ao produzir sinergia, constitui uma forte conexão para atingir objetivos pelo trabalho conjunto (EVANS, 1996), uma vez que atores estatais e não estatais são mobilizados e envolvidos na consecução de metas públicas e os laços entre cidadãos e funcionários intercruzam o limite atribuído entre público-privado. Essa conexão sinérgica é possível pela descentralização e abertura organizacional, que combatem a uniformidade e a rigidez burocrática, e criam, também, maior espaço para criatividade e inovação direcionadas às particularidades contextuais do plano local (EVANS, 1995; 1996). Isso não significa, no entanto, negar a burocracia; pelo contrário, as bases governativas devem sempre estar orientadas pelos seus princípios, pois, na ausência de uma estrutura administrativa coerente e auto-orientada, a autonomia inserida pode produzir efeitos nocivos tais como subordinação a laços clientelistas e a corrupção (EVANS, 1993; 1996).

A ideia de sinergia aproxima-se do conceito de permeabilidade do Estado proposto por Marques (2000, p. 53) ao indicar que Estado e sociedade não são instituições estanques e isoladas e constituem um poder infraestrutural "[...] a partir de uma teia de relações e cumplicidades [...], incorporando diferentes tipos de elos". De acordo com Evans (1996), seriam duas as suas fontes: a) dotações socioculturais oriundas do capital social historicamente construído e das propriedades das instituições governamentais, sendo externos aos agentes, uma vez que resultam do acúmulo de longo prazo; b) regimes organizacionais imaginativos oriundos da capacidade coletiva de empreender institucionalmente, isto é, propiciar inovação pela criação institucional.

Como algo acumulado historicamente, as dotações socioculturais são naturalmente constituintes das comunidades, traçando o seu destino e a capacidade sinérgica de Estado e sociedade para potencializar o bem-estar de todos. Já aqueles que não as têm estariam condenados pelo determinismo histórico-cultural - segundo compreensão de Putnam (1996) -, de maneira que em sociedades com "cidadania de baixa densidade", como o caso latino-americano (O'DONNEL, 1991), reformas institucionais estariam já destinadas ao fracasso. Entretanto, este autor deixa em aberto a possibilidade de governos criarem capital social.

Quando considerado o caso brasileiro, Marques (2000) recorda que a construção histórica das instituições no Brasil foi constituída por zonas de sombra na permeabilidade das relações Estado e sociedade. Nessas sombras estão as práticas mandonistas, personalistas, patrimonialistas e clientelistas até hoje presentes nas representações do imaginário nacional e de reformistas (COSTA, 2009), como também o controle corporativista autoritário do Estado sobre a sociedade (TAPIA, 1994), que não deixaram de ser reféns do hiato entre insulamento burocrático e captura de estruturas locais por práticas clientelistas (DINIZ, 1996).

Essas sombras, que deixam o Estado refém e restrito às elites e aos burocratas, levou a população a uma "[...] desconfiança em relação aos mecanismos tradicionais de representação política e de administração do Estado, percebidos como parte intrínseca do processo de exclusão" (FLEURY, 1999, p. 12). Há, portanto, no Brasil um duplo desafio para referenciar a autonomia inserida, a sinergia e a criação institucional. De um lado, a necessidade de efetivação de um aparato público profissionalizado e autônomo, pertinente a uma governança democrática que se inscreva em novas relações de poder; de outro, considerar

\footnotetext{
1 "Os anéis burocráticos não advêm da existência de solidariedades ou da possibilidade de busca de recursos políticos comuns entre camadas ou frações de classe mais amplas, mas [...] um interesse específico que pode unir, momentaneamente ou, em todo caso, não permanentemente, um "círculo de interessados" na solução de um problema [...] O que os distingue de um lobby é que são mais abrangentes (ou seja, não se resumem ao interesse econômico) e mais heterogêneos em sua composição (incluem funcionários, empresários, militares, etc.) e, especialmente que, para ter vigência no contexto políticoinstitucional brasileiro, necessitam estar centralizados ao redor do detentor de algum cargo" (CARDOSO, 1975, p. 208).
} 
que essa inserção demanda por uma cidadania completa, ou melhor, cidadãos empoderados por meio de uma inclusão ativa na comunidade política para definir metas públicas.

Evans (1996, p. 1130) não ignora as circunstâncias sociopolíticas adversas inerentes à realidade da baixa densidade da cidadania. Afirma, no entanto, que "[...] a prudência não pode ser desculpa para a paralisia [...] e ignorar as evidências de retorno para os esforços imaginativos e empreendedores na construção de sinergia é provavelmente um erro pior do que subestimar os obstáculos sociopolíticos ao seu resultado". Este é um desafio imaginativo e inovador que não tem sido ignorado, particularmente no contexto nordestino e especialmente no Semiárido brasileiro.

\section{PROCEDIMENTOS METODOLÓGICOS}

Esta é uma pesquisa qualitativa na qual foi adotado o método de estudo de caso único, com o objetivo de analisar as formas de inserção, das ações relacionadas ao P1MC, no Vale do São Francisco, especificamente na microrregião de Juazeiro, estado da Bahia. Este caso teve natureza instrumental, escolhido em razão de sua configuração favorecer a compreensão da questão de pesquisa (CRESWELL, 2007; STAKE, 2005; YIN, 2010), destacando-se que a microrregião selecionada representa um recorte significativo do contexto do Semiárido brasileiro, em virtude de seu papel na história de desenvolvimento do Programa.

A pesquisa foi direcionada ao aprofundamento da análise do fenômeno para melhor descrevê-lo e interpretá-lo (GODOY, 2006). Na coleta de dados deu-se especial atenção ao estabelecimento de um corpus que, de um lado, possibilitasse produzir um relato denso da trajetória do programa, identificando características específicas da política pública em construção, e, por outro lado, fosse direcionado a identificação e caracterização de elementos na análise de práticas de coprodução e/ou sinergia das relações Estado e sociedade, sendo utilizadas diferentes fontes de evidência (FLICK, 2009; YIN, 2010).

As fontes de dados orientaram-se para dois tipos de corpus, documentais e de entrevistas. A coleta foi organizada em duas etapas. Na primeira, os documentos serviram para a familiarização com o objeto de estudo, e se recorreu a uma variedade que permitiu compreender a trajetória dessa experiência em termos longitudinais e identificar as principais interações existentes. O objetivo com essa diversificação dos documentos, em termos de tipo e origem, foi o de ampliar a variedade de representações do corpus trabalhado (BAUER e AARTS, 2002), que se constituiu de estatutos; atas; materiais de divulgação; projetos; relatórios; editais; termos de convênio; cartilhas; notas de esclarecimento, entre outras. A segunda etapa consistiu de realização de entrevistas semiestruturadas que possibilitaram reconstituir a trajetória e compreender melhor as relações estabelecidas pela perspectiva dos sujeitos envolvidos. As entrevistas foram definidas seguindo os princípios da formação de um corpus de pesquisa baseado em "[...] uma coleção finita de materiais, determinada de antemão pelo analista, com [inevitável] arbitrariedade, e com a qual ele irá trabalhar" (BARTHES apud BAUER e AARTS, 2002, p. 44). Como recurso à ampliação das representações contempladas na pesquisa e para a constituição da amostra, que totalizou 22 (vinte e duas) entrevistas, fez-se uma sistematização de diferentes estratos de entrevistados: a) estrato A: indivíduos participantes da representação nacional do Fórum Asa Brasil e/ou da Unidade Gestora Central (AP1MC) (cinco entrevistas); b) estrato B: membros da Unidade Gestora Microrregional (UGM) na microrregião estudada (seis entrevistas); c) estrato C: membros das comissões municipais do P1MC na microrregião (cinco entrevistas); e d) estrato D: membros de famílias participantes do programa e beneficiárias das cisternas domiciliares nos municípios que compõem a microrregião pesquisada (seis entrevistas).

A análise dos dados foi baseada na técnica de análise de conteúdo (BARDIN, 2002), sendo realizada a pré-análise dos textos de documentos por meio da leitura flutuante com o objetivo de selecionar corpora relevantes, que foram analisados por meio de inferência e interpretação, caracterizando elementos temáticos mais significativos. Nas entrevistas especificamente, foram adotadas as técnicas definidas por Jovchelovitch e Bauer (2002), com a utilização dos seguintes passos: 1) transcrição detalhada do material verbal; 2 ) identificação dos elementos indexados nas histórias (que apresentam referências aos atores, acontecimentos, aspectos temporais e espaciais) e do material não indexado (expressam, para além dos acontecimentos, valores e juízos); 3) utilização do material indexado para, com base nas narrativas individuais, analisar e ordenar os acontecimentos; e 4) agrupamento das trajetórias dos indivíduos e estabelecimento do contexto que envolve as narrativas individuais, identificando trajetórias coletivas. Posteriormente, foi realizada triangulação dos dados dos documentos e das entrevistas a fim de codificá-los em bloco e averiguar a sua homogeneidade e pertinência. 


\section{ANÁLISE DOS RESULTADOS}

\section{Ação estatal e o Semiárido brasileiro: breve histórico}

Desde o seu primórdio, as políticas públicas para o Semiárido brasileiro caracterizaram-se pela centralidade da ação do Estado em oito dos nove estados nordestinos (Alagoas, Bahia, Ceará, Paraíba, Pernambuco, Piauí, Rio Grande do Norte e Sergipe) e parte do norte de Minas Gerais. Trata-se da região dos sertões, marcada pelas secas em virtude da baixa precipitação pluviométrica, caracterizada pela irregularidade de chuvas e sua concentração, além de elevados índices de evaporação, o que leva as populações locais a terem de conviver com deficits hídricos significativos por gerações, não apenas por causa das condições climáticas, mas, fundamentalmente, por conta das estruturas econômica, social e política ali implantadas com a ocupação colonial no século XVII.

Porém, a intervenção estatal nessa região foi inexistente até 1877-79, quando mais de 200 mil pessoas morreram em decorrência da tragédia da Grande Seca (CAMPOS, 2014). Ao longo das várias décadas seguintes, essa ação foi dirigida ao combate à seca dentro de uma realidade marcada por fome, flagelo, saques e insegurança - um cenário que remonta ao período colonial. Desse modo, as intervenções estatais adotadas a partir do final do século XIX constituíram-se em medidas emergenciais durante períodos prolongados de seca e, além disso, em construção de açudes, que, no entanto, privilegiavam muito mais os grandes proprietários rurais.

Por isso, como salientaram Chacon (2005) e Silva (2006), a existência de reservatórios na região não significava automaticamente acesso à água. Além do que, ações emergenciais, fortemente embasadas no assistencialismo, sempre se convertiam em mecanismo político para reforçar o mandonismo local, baseado no coronelismo regional da 1a República, tornando propícia a indústria da seca.

Em 1945, foi criada a Companhia Hidroelétrica do São Francisco (CHESF) dentro do escopo de ações que delineiam o nacional-desenvolvimentismo brasileiro e tiveram sua primeira expressão no planejamento de intenção quinquenal - a exemplo dos Planos de Obra e Equipamentos, Salte e Lafer, vinculada à construção da hidroelétrica de Paulo Afonso e da rodovia RioBahia. Neste mesmo ano, também foi criado o Departamento Nacional de Obras contra as Secas (DNOCS) com a intenção de constituir um novo marco institucional na busca de soluções para o combate às secas.

Não obstante, essa inversão econômica programada, que orientou os investimentos em infraestrutura para alavancar inicialmente o processo de industrialização brasileiro no contexto nordestino, pouco ou nada contribuiu para alterar a dinâmica de subalternidade das relações sociais no Semiárido brasileiro - ou seja, as instituições como reflexo de um Estado voltado àqueles que estão no poder, o que incluía as oligarquias regionais constituintes do pacto corporativista que deram sustentação ao Estado Novo e aos governos seguintes.

Por sua vez, no escopo do Plano de Metas do governo JK (1955-60), o desenvolvimentismo brasileiro começou a focar a questão da integração nacional sobre bases regionais - em 1959 foi criada a Superintendência de Desenvolvimento do Nordeste (SUDENE) com a pretensão de preencher esse hiato (CANO, 2010; FERREIRA, 2009). Antes, no entanto, em 1952, foi criado o Banco do Nordeste do Brasil (BNB) com o propósito de desenvolver economicamente a região por meio de empreendimentos industriais e agroindustriais. Porém, apesar de trazerem um forte impulso para mudanças estruturais socioeconômicas e políticas na região, essas criações institucionais não deixam de ser capturadas pelas elites locais, sendo alvo de uma regulação fisiológica e clientelista que conviveu com uma tecnocracia a operar entre a paralisia ou a barganha instrumental na implementação de ações.

Se, por um lado, com o Estado Novo vislumbrou-se acabar com a influência dos poderes locais, anteriormente vinculados ao sistema político do coronelismo na região (COSTA, 2009), por meio da adoção de práticas burocráticas centralizadas pelo governo federal; por outro lado, a criação de uma autarquia descentralizada e insulada burocraticamente como a SUDENE - com a proposta de atuar sobre os problemas regionais de outra maneira (SILVA, 2006), indicando especificamente para a região semiárida a adoção de uma economia adequada ao meio físico (BRASIL, 1959) - não foi suficiente para efetivar reformas institucionais no contexto do Semiárido brasileiro. Assim, os fundamentos microinstitucionais das relações Estado e sociedade, de que trata Evans (1993; 1995; 1996), não propiciaram vislumbrar uma autonomia inserida na atuação estratégica do 
Estado, juntamente com os agentes locais, capaz de articular uma nova dinâmica institucional de interesses coletivos para a consolidação das proposições de desenvolvimento regional pretendidas.

Por certo, é necessário considerar que o desenho institucional da SUDENE não se desenvolveu politicamente, sendo aprisionado pelos guardiões da ordem burocrática autoritária instalada pelos governos militares a partir de 1964. Assim, a capacidade de ação direcionada ao interesse coletivo por um desenvolvimento regional apropriado ao contexto do Semiárido, empreendida pelo Estado brasileiro desenvolvimentista, logo no início da década de 1960, não pôde atestar a criatividade e a qualidade dessa nova forma organizacional em capitalizar mudanças institucionais.

Como regime organizacional imaginativo, a SUDENE foi capturada pela tecnocracia dos Planos Nacionais de Desenvolvimento (PNDs) entre 1970 e 1984, que buscaram o fortalecimento de instituições governamentais sem considerar a necessidade de acumulo histórico de capital social para a dinamização do tecido socioeconômico e político regional. Desse modo, uma reforma por meio da ação planejada do Estado, tendo o governo federal como o único agente a empreender mudanças institucionais, antes intentada pelo desenho original da SUDENE, não transpôs o path dependence histórico-cultural de interações público-privado sobre bases patrimonialista e clientelistas da região.

A dinâmica econômica alavancada por uma política de desenvolvimento regional a partir de 1970 foi marcada pelo conservadorismo político e social. Um período caracterizado por uma modernização conservadora orientada para grandes projetos de irrigação e para a dinâmica econômica de polos de crescimento fundados no desenvolvimento industrial e de agroindústrias. Isso possibilitou novas formas de acumulação do capital, que beneficiaram grandes proprietários e grupos econômicos nacionais e internacionais, ao mesmo tempo que as estruturas fundiárias, de renda e política, reconhecidas como responsáveis pelo atraso social da região, foram preservadas, e o bioma Caatinga, devastado (SILVA, 2006).

Os projetos governamentais utilizavam-se de novos modelos organizacionais de gestão e apoio científico e tecnológico oriundos de países centrais para dinamizar novos empreendimentos e o crescimento econômico na região. Foram criadas, em 1974, a Companhia de Desenvolvimento do Vale do São Francisco (Codevasf) e, em 1973, a Empresa Brasileira de Pesquisa Agropecuária (Embrapa). Ambas constituídas como empresas públicas dotadas de flexibilidade administrativa para cumprir as missões de caráter fundamentalmente técnico que lhes foram atribuídas, quais sejam: a promoção do desenvolvimento da região do Vale do São Francisco com ênfase nos projetos irrigação, no caso da primeira; a implantação do sistema nacional de pesquisa agropecuária para atender as necessidades tecnológicas do desenvolvimento agrícola brasileiro, no caso da segunda.

A modernidade de modelos organizacionais cria, no entanto, "ilhas de modernização" no contexto do Semiárido (SILVA, 2006), caracterizando-o pela convivência dual entre o moderno e o tradicional, que se evidencia por conta dessa "modernização seletiva" (ARAÚJO, 2000). Como resultado, permanece o path dependence às velhas práticas de dominação política, econômica e social, uma vez que as medidas governamentais de modernização não foram suficientes para transformar a concentração de renda e a exclusão social - o acesso à água continuou vinculado aos fins produtivos dos grandes proprietários de terra e grupos econômicos nacionais e internacionais, enquanto a população sertaneja pobre permaneceu à espera de uma ação do Estado que lhe fosse mais próxima e apropriada.

As transformações introduzidas sobre os pressupostos da modernização conservadora, apesar de produzirem ilhas de modernização econômica, não resultaram em mudança institucional. Assim, as instituições criadas exclusivamente por uma ação top down do planejamento do governo federal evidenciaram sua limitação na reversão de caminhos, apesar das pretensões instrumentais de seus estrategistas.

\section{UMA OUTRA HISTÓRIA: DAQUELES PARA OS QUAIS A AÇÃO ESTATAL NÃO SE FEZ PRESENTE}

Araújo (2000, p. 265) observa, no entanto, diversas mudanças no Semiárido brasileiro nas últimas décadas. Entre elas destaca novos atores, como as ONGs que têm ocupado os "espaços de não presença do Estado". No Vale do São Francisco, a microrregião de Juazeiro localizada no Norte do estado da Bahia - em fronteira com os estados de Piauí e Pernambuco e composta pelos municípios de Campo Alegre de Lourdes, Pilão Arcado, Remanso, Sento Sé, Casa Nova, Sobradinho, Juazeiro e Curaçá - é um exemplo desses espaços, apesar de também pertencer à dinâmica do polo de crescimento econômico da fruticultura irrigada para exportação de Petrolina-Juazeiro. 
Nessa microrregião a ação de entidades da sociedade civil direcionada à população rural sertaneja pobre remonta a meados da década de 1970. Um momento no qual a Igreja Católica voltou-se aos problemas vivenciados pelas famílias rurais pobres, dando suporte a agentes pastorais, ativistas voluntários e profissionais diversos para realizar ações de desenvolvimento comunitário. Entre as várias iniciativas de apoio desenvolvidas nessas comunidades rurais, destacam-se a regularização fundiária, o acesso aos benefícios da seguridade social, a alfabetização de jovens e adultos, a organização sindical - todas orientadas para a luta e a conquista de direitos dessa população à terra, à organização associativa e ao acesso à água.

Essas ações combatem causas seculares e estruturais da miséria no Semiárido brasileiro - denunciadas por várias décadas -, esperando por uma "transformação social que, em essência [é] também uma transformação política" (ANDRADE, 1993, p. 29), ou, como afirmava Josué de Castro (1967), a seca e a fome são um problema de economia política. Assim, como observam Carvalho e Egler (2003), se soluções hídricas como a irrigação poderiam transformar o Semiárido, isto só se concretizaria efetivamente quando fossem transformadas as relações econômicas e políticas atrasadas que sempre marcaram a região, passando pelo acesso de todos à água.

Por isso, sobretudo após a segunda metade da década de 1980, o problema de acesso à água por parte das comunidades rurais pobres, além de ser alvo de ação comunitária em virtude da necessidade de buscar soluções para a insegurança hídrica dessa população, tornou-se uma bandeira de luta por direitos. Como destaca Malvezzi (2007), o problema da falta d'água no Semiárido refere-se muito mais ao acesso regular do que ao seu volume. A falta de acesso ocorre especialmente para os mais pobres, que são muitíssimo mais fragilizados nos períodos de seca em virtude da estrutura socioprodutiva da região. Há dois tipos de escassez: qualitativo, quando há a degradação dos mananciais; social, quando, além de haver apropriação privada das águas, o poder público não assegura uma distribuição igualitária (MALVEZZI, 2007).

No início da década de 1990, essa luta toma contornos de um movimento social vigoroso, congregando um conjunto de organizações da sociedade civil que foram sendo criadas e articuladas em torno das ações dinamizadas inicialmente pela Igreja Católica no empoderamento de comunidades pobres. A inserção da Igreja, ainda na década de 1970, possibilitou a mobilização e o incremento do capital social dessa população, que, munida de um sentido cívico na luta por direitos, organizou-se para empreender mudanças.

Desse modo, na segunda metade da década de 1990, um conjunto de iniciativas organizadas por sindicatos, associações comunitárias e ONGs estava em andamento visando reduzir a vulnerabilidade de famílias rurais pobres no que diz respeito ao acesso à água potável para consumo humano, além de lutar pelo direito à terra, à moradia, à preservação ambiental e à dignidade humana e atuar na criação e fortalecimento de um associativismo/cooperativismo da agricultura familiar com inclusão socioprodutiva sustentável e solidária. Todo esse processo orienta-se a um aprendizado contínuo facilitador do empoderamento de sujeitos que, ao exercerem sua expressão sociocultural plenamente, podem se libertar das antigas rotinas de subserviência e dependência de favores.

A resignação das populações rurais pobres diante de medidas emergenciais precárias e clientelistas de combate à seca transforma-se durante mais uma seca entre 1992 e 1993. Com a sede da SUDENE, em Recife/PE, ocupada por manifestantes, denuncia-se a necessidade imediata de enfrentamento dos problemas do acesso à água de forma mais direcionada e resoluta. Na seca de 1998-1999, a Diocese da Igreja Católica de Juazeiro encabeça a Campanha Adote uma Cisterna, em parceria com diversas organizações da sociedade civil.

O objetivo da campanha, além de arrecadar fundos para a construção de cisternas de placa de cimento, - a tecnologia social desenvolvida para resolver o problema de abastecimento de água das famílias rurais (ANDRADE, CORDEIRO NETO e VALADÃO, 2013) - foi denunciar a falta de políticas públicas para diferentes classes e grupos sociais e a necessidade de transformar o entendimento atávico de que a resolução dos problemas do Semiárido perpassaria exclusivamente pelo combate à seca, sem enfrentar os problemas da estrutura social, econômica e política da região. Como destacado, essa

Campanha tinha o objetivo de denunciar a seca aqui na região, colocando [...] o que não tinha era políticas públicas [...] políticas públicas de convivência com o clima [...] se denunciou a falta de políticas públicas pra região Semiárida. (ENTREVISTA B.V).

Explícita estava a compreensão de que ao longo de décadas não existiram políticas públicas efetivas para a resolução de problemas e o acesso a direitos da população sertaneja pobre. Como destacam Medeiros, Silveira e Neves (2010), a relação 
dessas comunidades com o Estado sempre foi marcada pela dependência política: eram identificadas como "receptoras de doações governamentais", como no caso do acesso à água. Ou seja, práticas clientelistas capturavam a obrigação do Estado de atender um direito, e o abastecimento de água, por meio de carros-pipa e construções hidráulicas mal planejadas, era incorporado como mecanismo de reforço à "[...] dependência política das pessoas em relação aos governos locais" (MEDEIROS, SILVEIRA e NEVES, 2010, p. 12).

Essas comunidades haviam ficado distantes de políticas públicas de modernização empreendidas quando da implantação de polos de crescimento econômico na região pelos governos militares entre as décadas de 1970 e 1980 . Entretanto, como destacam Andrade, Cordeiro Neto e Valadão (2013), em decorrência do processo associativo articulado a um conjunto de iniciativas técnicas que buscaram, distante de ações estatais, encontrar soluções para o problema de acesso à água, foi possível gerar alternativas sociotécnicas que orientaram medidas estratégicas para garantir um abastecimento de água consistente ao consumo das famílias rurais pobres na microrregião de Juazeiro.

Tais associações têm sua origem nas ações empreendidas ainda na década de 1970, que fortaleceram laços intracomunitários (CORDEIRO NETO, VALADÃO e ANDRADE, 2014). Assim, foi constituído um dos dois tipos básicos de capital social definidos por Putnam (1996), o que se dá por meio de vínculos daqueles que compartilham situações similares e de identidade, constituindo grupos sociais homogêneos, denominado capital social de aproximação/ligação. Ademais, esses laços ganharam contorno de capital social de ponte (o segundo tipo definido por Putnam) quando outros grupos começaram a constituir os links de uma rede de comunicação ao longo dos anos de 1980.

Essas ligações, no entanto, adquirem uma dimensão mais ampla na medida em que são estabelecidas relações sociotécnicas com o envolvimento de um maior número de organizações da sociedade civil durante a década de 1990. Isto é, as redes de comunicação identificadas por Assis (2006) e Cordeiro Neto, Valadão e Andrade (2014), no caso do P1MC, foram adensadas por relações interorganizacionais, que constituíram translações e fizeram emergir a tecnologia social das cisternas de placas de cimento, dando sustentação ao programa. (ANDRADE, CORDEIRO NETO e VALADÃO, 2013).

Esse processo propiciou a criação institucional da Articulação do Semiárido Brasileiro (ASA Brasil). Mais especificamente durante a realização de um fórum paralelo, quando ocorreu a III Conferência Internacional sobre Desertificação (COP III), promovida pela ONU, na cidade de Recife/PE, em novembro de 1999. Diversas das organizações da sociedade civil ali presentes elaboraram a Declaração do Semiárido, que deu consistência discursiva à convivência com o Semiárido como pressuposto orientador de um projeto para o desenvolvimento sustentável da região.

Silva (2006) apropriadamente destaca que a significação de convivência remete à ideia de "viver com", de "coabitar um espaço comum", o que implica uma lógica de reciprocidade e isso vale para os seres vivos de maneira geral. Ou seja, cultura e natureza não estão dissociadas em polos distintos (LATOUR, 1994). Assim, não é a realidade do Semiárido brasileiro que deve se adaptar aos pressupostos modernizadores do desenvolvimento econômico, mas, sim, a economia que deve ser permeada pelo meio ambiente desse Semiárido. Algo já destacado há muitas décadas por pensadores brasileiros e nordestinos, a exemplo de José Guimarães Duque, Josué de Castro, Manuel Correia de Andrade, entre outros.

\section{O ASSOCIAR DA CONVIVÊNCIA COM O SEMIÁRIDO: ARTICULANDO A CONSTRUÇÃO DE CISTERNAS}

A Articulação do Semiárido Brasileiro (ASA Brasil) foi criada tendo por base a reciprocidade e, nos termos de Latour (2001), transladou uma socialização maciça por meio da composição de inúmeros materiais heterogêneos, o que possibilitou a autonomização dessa congregação invisível composta por mais de 700 organizações da sociedade civil mobilizadas naquela região mediante práticas e princípios de convivência com o Semiárido.

A ASA Brasil defende a captação e o armazenamento adequado da água da chuva por meio de cisterna de placa de cimento como o recurso mais apropriado para dar acesso e atender as necessidades de consumo das famílias rurais pobres na região. Essa alternativa está dentro das propostas de convivência com o Semiárido e é orientada a pequenas ações no lugar de grandes obras e à luta por políticas públicas inclusivas que se quer vincular a um projeto de desenvolvimento sustentável para a região (MEDEIROS, SILVEIRA e NEVES, 2010). 
Essa proposição explícita de projeto de desenvolvimento chama também a responsabilidade do Estado, o que está expresso na Declaração do Semiárido. Buscou-se, nesse caso, uma articulação com os representantes do Ministério do Meio Ambiente (MMA) durante a COPIII. Além de capitalizar o interesse governamental nas cisternas, a ASA Brasil propõe o conjunto de ações sociotécnicas sistematizadas para solucionar o problema de acesso à água como meio para garantir a universalização da água no Semiárido (ASSIS, 2006; ANDRADE, CORDEIRO NETO e VALADÃO, 2013).

Em 1999, o Programa Um Milhão de Cisternas (P1MC) emergiu, incipientemente, com a articulação da ASA Brasil, para dar escala à construção das cisternas, o que já vinha sendo realizado pelas organizações da sociedade civil. Nos anos que se seguiram, de 2000 a 2002, projetos experimentais foram financiados pelo Governo Federal, especificamente pelo MMA por intermédio da Agência Nacional das Águas (ANA). Em 2003, com a criação do Ministério Extraordinário de Segurança Alimentar (MESA), o P1MC foi inserido na Política Nacional de Segurança Alimentar e Nutricional e passou a ser financiado com recursos do Programa Fome Zero, sendo, posteriormente, incorporado, no ano de 2004, às ações do Ministério do Desenvolvimento Social (MDS). (ASA, 2011; BRASIL, 2006).

Como programa vinculado ao MDS, os recursos para a construção de cisternas são repassados para a Associação Gestora do Programa Um Milhão de Cisternas Rurais (AP1MC), uma Organização da Sociedade Civil de Interesse Público (OSCIP), especialmente criada para geri-los por meio de Termo de Convênio. Composta pelo Fórum ASA, a AP1MC celebra, por sua vez, Termos de Cooperação Técnica e Financeira (TCTF) com organizações selecionadas nas microrregiões do Semiárido, constituindo estas como Unidades Gestoras Microrregionais (UGM) do programa. Cabe às UGMs o gerenciamento das ações do programa nos municípios sob sua área de abrangência, com o apoio de uma Comissão Municipal composta por representantes das organizações locais, especialmente criada para dar apoio à gestão, bem como na transparência do processo de seleção e atendimento das famílias (ASA, 2011; MDS, 2010).

As famílias participantes do P1MC são selecionadas com base nos critérios pré-estabelecidos pelo MDS. O público alvo são as famílias em situação de insegurança alimentar e nutricional, cujas residências não estão contempladas por rede de abastecimento. São prioritárias aquelas nas quais as mulheres são o chefe de família e que tenham maior número de crianças e adolescentes em fase escolar, bem como de idosos e/ou deficientes físicos (BRASIL, 2006; MDS, 2010).

Conforme a metodologia da ASA Brasil, a família beneficiada é também corresponsável pela implantação do programa, cabendo participar das capacitações referentes à gestão da água para consumo e produção de alimentos que são ofertadas pela UGM. Também são de sua responsabilidade a escavação do solo onde a cisterna será instalada e apoio com hospedagem, alimentação e mão de obra auxiliar ao pedreiro contratado pela UGM para a construção da cisterna (BRASIL, 2006; MDS, 2010).

Houve, assim, uma nova permeabilidade entre Estado e sociedade com a incorporação do P1MC na Política Nacional de Segurança Alimentar e Nutricional. Entretanto, a presteza do governo federal em encampá-lo não significou falta de déficits de implementação. Ressalte-se que as particularidades do contexto institucional do Semiárido e a capacidade de governança das instituições estatais em termos locais devem ser mais bem analisadas.

\section{SINERGIA ESTADO E SOCIEDADE: UMA ANÁLISE DAS RELAÇÕES LOCAIS DO P1MC}

Conforme se observou anteriormente, as ações que levaram à criação da ASA Brasil e à constituição do P1MC originaram-se exclusivamente da iniciativa de organizações da sociedade civil. Lembrando que, em âmbito local e regional, as relações dessas organizações com as organizações estatais foram sempre permeadas por conflitos e contradições. Destarte, a análise da sinergia institucional, conforme proposto por Evans (1993; 1995; 1996), considera as propriedades governativas do conjunto de instituições em sua capacidade de complementaridade e inserção autônoma para concretizar metas públicas comuns.

Ao mesmo tempo que o P1MC tem suas bases descentralizadas e vinculadas à ação organizacional da ASA Brasil, que foi quem Ihe concebeu, adquire caráter governamental no momento de sua vinculação ao Plano Plurianual (PPA)-Brasil. Para firmar o convênio com o MDS, foi necessário, no entanto, criar a AP1MC a fim de operá-lo e atender a exigências legais, constituindo, assim, uma parceria público-privada. 
Ao mesmo tempo, o desenho do programa, que passou a ser coordenado pelo MDS, prevê o estabelecimento de parcerias em âmbito intergovernamental com as prefeituras de cada município das microrregiões. Além disso, dentro do escopo da intersetorialidade, o MDS estabelece parcerias com outros ministérios e empresas estatais a ele vinculados e que têm forte enraizamento no Semiárido, como é o caso da Codevasf e da Embrapa, considerando a execução técnica do P1MC.

Deve-se salientar, entretanto, que, se, de um lado, há uma complementaridade quando firmado o convênio ASA-MDS na coprodução do P1MC em maior escala em todo o Semiárido a partir de 2004; de outro, a imersão autônoma das organizações governamentais atuantes no âmbito local/regional ocorreu de modo incipiente ao longo dos anos anteriores àquela institucionalização do programa. A seguir, é analisada a dinâmica de envolvimentos dessas organizações estatais com as organizações da sociedade civil, vinculadas à ASA Brasil, em sua capacidade de gerar sinergia.

\section{Empresas do governo federal atuantes no Semiárido}

As relações com a Codevasf são marcadas por serem muito pontuais e descontínuas. Conforme indicou um dos entrevistados, o acesso aos quadros gestores variava conforme o perfil do gestor à frente da superintendência. Porém, isso não implicou a falta de colaboração dos quadros técnicos dessa instituição com as organizações vinculadas às comunidades rurais, havendo uma proximidade por parte de alguns funcionários com as atividades desenvolvidas pelas organizações da sociedade civil.

Por exemplo, no início dos anos 1990, a Codevasf disponibilizou assistência técnica de engenheiros e outros profissionais para assessorar a elaboração de planos de abastecimento hídrico propostos pelas organizações da sociedade civil, a fim de se constituírem em projetos de lei nas câmaras de vereadores dos municípios da microrregião de Juazeiro. Esses profissionais disponibilizaram pareceres técnicos e estudos sobre a viabilidade de barragens nos municípios, avalizando a proposta de que os represamentos seriam uma boa opção para o aproveitamento dos recursos hídricos em algumas daquelas localidades. Esses projetos, no entanto, não foram adequadamente considerados pelos legislativos municipais, evidenciando-se as distâncias, contradições e os conflitos anteriormente indicados.

Deve-se destacar que essa maior proximidade foi pontual. Ao longo dos anos, a incipiência colaborativa foi aquilo que marcou as relações da Codevasf com as organizações da sociedade civil que, posteriormente, em 1999, vieram a compor a ASA Brasil.

Ao mesmo tempo, com a institucionalização do P1MC - que consolidou as cisternas de placa de cimento juntamente com a capacitação das famílias rurais na sua construção, gestão e manejo da água para consumo domiciliar e para a produção de alimentos de modo participativo e solidário, constituindo as bases metodológicas e pedagógicas dessa tecnologia social de convivência com o Semiárido -, o que se observou foi um conflito de interesses entre a Codevasf e as organizações da sociedade civil vinculadas à ASA Brasil. Isso foi indicado por alguns entrevistados, como na fala a seguir:

Em alguns momentos criou até dificuldades, porque já chegou ao ponto de, na mesma comunidade, você tá construindo uma cisterna com todos os critérios da ASA, com toda essa questão e tal, e na mesma comunidade uma família tá recebendo uma cisterna tendo que botar areia, tendo que trabaIhar, e a outra família tá recebendo do lado uma que recebia dinheiro pra tudo, pra trabalhar, pra botar areia, recebia tudo da empresa, até a comida do período, recebia tudo. (ENTREVISTA B.V).

A Codevasf, de colaboradora eventual, transformou-se em uma concorrente. Com a implementação do P1MC, sob a coordenação do MDS, em virtude da demanda de ampliar a escala de atendimento do programa e atingir as metas traçadas para o PPA-2012/2015 (Brasil sem Miséria), as ações daquele programa foram incorporadas pelo Programa Água para Todos. Dentro desse escopo do planejamento governamental federal, a Codevasf buscou atingir as metas por meio da contratação de empreiteiras e adotou cisternas polietileno com contratação gerenciada pelo Ministério da Integração (CAMPOS e ALVES, 2014). Além disso, utilizou um tipo de cisterna diferente, não considerou as bases pedagógicas de capacitação, participação e responsabilização das famílias beneficiárias na execução do programa.

Outra empresa pública presente na região é a Embrapa, mais especificamente o Centro de Pesquisa do Trópico Semiárido (CPTSA), localizado em Petrolina/PE. Com este as organizações da sociedade civil sempre tiveram proximidade e interação direcionadas ao desenvolvimento técnico de alternativas eficientes e adequadas de reservatórios de água para consumo humano na região, o que culminou na tecnologia social das cisternas de placa de cimento. Assim, quando da criação do 
Instituto Regional da Pequena Agropecuária Apropriada (IRPAA) na década de 1990, esta ONG foi apoiada e fortalecida pelo CPTSA/Embrapa. As duas organizações estabeleceram parcerias para o desenvolvimento de tecnologias agropecuárias adequadas às propriedades de pequenos produtores rurais e suas atividades vieram a constituir campo de interesse de pesquisa, conforme expôs um dos entrevistados:

A Embrapa, para ela é interessante porque nós, assim... provamos as tecnologias desenvolvidas, né... disponibilizamos um campo para eles interessante de pesquisa, nas comunidades... (ENTREVISTA A.II).

Outra colaboração entre o IRPAA e o CPTSA/Embrapa ocorreu para realizar a Conferência da International Rainwater Catchment Systems Association (IRCSA) no ano de 1999, em Petrolina. Essa conferência possibilitou congregar as diversas organizações da sociedade civil em um único lugar para discutir alternativas técnicas à captação e ao acesso à água e para firmar os princípios da convivência com o Semiárido. Tudo isso repercutiu na consolidação da tecnologia social das cisternas de placa de cimento e na elaboração do P1MC.

Desse modo, estabeleceu-se uma colaboração intensa entre as organizações que compõem a ASA Brasil e a Embrapa ao longo dos anos. Essa parceria está direcionada a relações científicas e tecnológicas dentro daquilo que constitui os objetivos de atuação daquela empresa pública. Ou seja, não há um envolvimento direto da Embrapa na execução do programa e apoio na capacitação tecnológica das famílias de agricultores. Como sintetizou um dos entrevistados:

Temos acesso a informações, pesquisas. E o grande problema da Embrapa é que ela não chega assim ao povo simples muito fácil, né? [...] A Embrapa tá à disposição pra informar, né? Só que o pequeno não vai pra lá, né? Ele às vezes não tem os meios, tem medo, não se sente bem lá. Então, através dessa... desse intercâmbio, né? [...] Então, a gente consegue abrir um pouco a Embrapa para o povo mais simples. (ENTREVISTA A.II).

Nestes casos, observa-se que o movimento que deu sentido à criação institucional da ASA Brasil como uma experiência exclusivamente bottom-up, ou melhor, grass-root, mesmo intentando proximidade com aquelas organizações burocráticas, não foi capaz de inseri-las na nova trajetória proposta. Isso não significa, no entanto, que a Codevasf e a CPTSA/Embrapa ficaram prisioneiras das trajetórias políticas do contexto no qual estavam enraizadas, incapazes de empreender mudanças, conforme sugerido por Côrtes (2009). Mais do que tudo, essas empresas públicas ficaram prisioneiras da gaiola de ferro weberiana, dando prioridade a processos tecnocráticos e sua eficiência, incapazes de uma proximidade que privilegiasse uma reciprocidade com a sociedade e suas organizações sociais.

\section{Poder local: as armadilhas do path dependence}

Desde o início da década de 1990, muitas das organizações da sociedade civil que compõem a ASA Brasil trabalharam para o desenvolvimento da tecnologia social das cisternas de placa de cimento e também a metodologia de capacitação de gestão da água das comunidades rurais vinculadas à microrregião de Juazeiro. Assim, todo o conjunto de atividades desenvolvidas e sistematizadas ao longo desses anos - que veio a compor a proposta do P1MC - foi orientado pelos princípios da convivência com o Semiárido, procurando marcar uma ruptura com práticas de combate à seca predominantes na região, conforme um dos entrevistados:

Num se falava em política pública naquela época. [...]. Chegasse... qualquer obra que chegasse numa comunidade era tido assim como uma esmola. E a gente, assim com a cisterna, tentou envolver desde o início as comunidades pra que isso não chegasse também como... como chegavam as outras coisas que a gente via por outras vias. (ENTREVISTA B.V).

Também, nessa mesma época, intentou-se uma aproximação com o poder público local. Sob a coordenação da Diocese de Juazeiro, juntamente com sindicatos e associações das comunidades rurais, tentou-se fazer da construção de cisternas domiciliares um componente constante no orçamento das prefeituras locais por meio de leis de iniciativa popular. Entretanto, a 
resistência e recusa do poder público local (prefeituras e câmaras de vereadores) para com esses projetos foi muito forte perdeu-se uma oportunidade relevante na renovação das bases de relação entre Estado e sociedade na região.

Assim, durante os anos de 1990 e início do século XXI, as atividades desenvolvidas pelas organizações da sociedade civil vinculadas à ASA Brasil encontraram de modo geral por parte daqueles representantes do poder público local muita resistência e entraves para as ações desenvolvidas. Em muitos casos ocorreu mesmo uma oposição deliberada, marcada por relações hostis, das quais a fala a seguir é uma representação:

Como é que eu coloco isso? [Pausa; reflexivo] Eu queria colocar assim... é... O programa, de certa forma... é... fez com que... muitos gestores municipais, né... mudasse a forma de agir [pausadamente, refletindo na formulação]. Porque durante esse programa, nós recebemos até ameaça de prefeito de derrubar, passar a máquina em cima da cisterna... (ENTREVISTA B.V).

Esse quadro contribuiu para que se apresente na região, pelo menos no âmbito da experiência estudada, a predominância de uma visão na qual seria muito remota a possibilidade de que poder público e sociedade civil possam compartilhar ações em projetos bem sucedidos. Ou seja, não haveria a possibilidade do estabelecimento de metas públicas comuns, pois a posição do poder público local já seria um entrave a qualquer possibilidade de sinergia institucional que alterasse o path dependence do mandonismo local.

Ao mesmo tempo deve-se considerar que o empoderamento da população rural nas últimas décadas e o desenvolvimento de suas capacidades organizativas possibilitaram a criação institucional representada pela articulação da ASA Brasil. Essa transformação, no entanto, ocorreu sob a indiferença da gestão pública local frente às ações em questão, reforçando o indicativo da impossibilidade de se gerar sinergia, como relata um dos entrevistados:

Nem parceria e nem uma perseguição. Não percebo. Há... uma coisa, como se não fosse deles, eles não se interessam, não se envolvem muito. (ENTREVISTA C.I).

Assim, os atores locais envolvidos com o P1MC evitaram sempre a aproximação com alguns órgãos públicos, em especial com as prefeituras. Também os beneficiários ficam distantes em virtude de uma preocupação com possíveis capturas clientelistas por parte do poder público municipal e da política partidária, de modo que o contato com as famílias participantes ocorre diretamente com as comissões municipais e a UGM, responsáveis pela gestão do programa em cada município.

Desse modo, o programa tem sido operado com o cuidado de se distanciar dos padrões históricos de relacionamento com lideranças políticas locais. Ao mesmo tempo, a necessidade por parte da ASA Brasil de proteger suas ações do uso clientelista dos governos locais não tem favorecido uma maior aproximação com o poder público local e uma abertura maior para a criação de formas de convivência sinérgicas.

A inserção do programa na dinâmica de atendimento das políticas sociais por parte do MDS fez com que houvesse a exigência de registro das famílias participantes do P1MC no Cadastro Único (Cadúnico) da assistência social. Esse cadastro do governo federal incorpora todo o conjunto de benefícios sociais, em especial o Bolsa Família, e sua operação tem atribuição e responsabilidade das prefeituras em cada município, uma vez que há a descentralização constitucional dessas políticas públicas.

A complexidade institucional definida para a gestão das políticas sociais, desde 1988, demanda por novos posicionamentos por parte da gestão pública local. Isso não impede, no entanto, que não haja inúmeros problemas na implementação do sistema único de assistência social (SAS) que reflitam na destreza em implantar as famílias do P1MC como beneficiários no Cadúnico.

Essa aproximação via SAS abriu um espaço de diálogo entre as organizações da sociedade civil e as organizações públicas locais. Também, o poder público local buscou em alguns municípios uma maior proximidade com as comissões municipais e equipes gestoras do programa, como relatado a seguir:

Então, começou assim. Veio prefeito, veio vereador, veio esse pessoal. Em Sento Sé, o prefeito me chamou para fazer um... no primeiro projeto. Chamou para fazer uma reunião com a câmara de vereadores. Eu falei 'vou, que que eu perco?'. Terminou a reunião, ele falou: "o que a gente pode ajudar?". Eu falei: "muita coisa, agora não espere nada da nossa parte". (ENTREVISTA B.VI). 
A participação das prefeituras, mesmo que na maioria das vezes se desse de forma esporádica, foi importante em diversas circunstâncias para transpor dificuldades pontuais no que diz respeito à construção das cisternas. Porém, essas relações não conseguiram ser adensadas, pois, quando as prefeituras se propuseram a colaborar com as organizações da sociedade civil, falharam muitas vezes naquilo que haviam se comprometido.

A ocorrência dessas situações parece ter gerado nas organizações da sociedade civil, bem como nas comunidades de agricultores, a confirmação de que não é possível planejar ações conjuntas, muito menos definir metas públicas em comum. Assim, está ausente, sobretudo entre o público beneficiário do P1MC, uma compreensão de que o programa seja resultado de uma cooperação entre Estado e sociedade.

\section{CONSIDERAÇÕES FINAIS}

O objetivo neste artigo foi discutir como a criação de novos arranjos institucionais possibilita gerar sinergia nas relações Estado e sociedade e induzir, com isso, à mudança institucional. A análise histórica das políticas públicas direcionadas ao Semiárido brasileiro aqui realizada revelou, no entanto, o quanto pouco promissora parece ser a geração dessa sinergia, apesar de se evidenciar a capacidade de criação institucional na região.

Na verdade, no contexto em questão, a relação Estado e sociedade tem sido marcada há muitos séculos por um contraditório em que a presença de um determinada a não presença do outro, criando entraves à configuração de arranjos potenciais para o compartilhamento de ações e o estabelecimento de metas públicas comuns. Assim, a criação institucional da ASA Brasil, que possibilitou a formatação do P1MC baseando-se na realidade das comunidades rurais beneficiadas pelo programa, não facilitou a transformação do modo excludente como são percebidos esses sujeitos por parte dos poderes locais. Entretanto, também deve ser considerado, como os dados deste estudo indicam, aquilo destacado por Fleury (1999): a marca dessas relações de exclusão, ao longo de séculos, conduziu a uma forte desconfiança dessas comunidades para com os poderes instituídos.

Desse modo, a relação com os poderes públicos locais é, quase sempre, marcada pela hostilidade e pela ausência de colaboração sistemática. Esse é o entendimento daqueles envolvidos com a gestão do programa em todos os estratos pesquisados, a indicar a crença de que prevalece um setor público orientado para fins particularistas e clientelistas dos quais as organizações gestoras da sociedade civil devem proteger o programa mantendo o distanciamento necessário.

Isso é particularmente representado pelas prefeituras municipais, pois as relações com as organizações públicas federais, especificamente a Codevasf e o CTPSA/Embrapa, que revelaram ser muito pontuais, são marcadas por um distanciamento insulado por parte destas e não por iniciativa das organizações da sociedade civil. Essas observações permitem problematizar a importância da descentralização e da abertura organizacional nas organizações públicas como facilitadores da inserção do Estado em redes colaborativas da sociedade.

Quando considerada a descentralização, verifica-se que a implantação de empresas públicas vinculadas ao governo federal, ainda na década de 1970, como a Codevasf e a Embrapa, não permitiu o estabelecimento de relações de proximidade que pudessem constituir-se em laços institucionalizados com as organizações da sociedade civil vinculadas às comunidades rurais e aos pequenos agricultores. A abertura organizacional dessas empresas, quando existiu, ocorreu muito mais em razão de laços informais, o que não permite caracterizá-los como uma complementaridade, pois não houve nem mesmo a intenção de estabelecer uma divisão de atividades para atingir objetivos comuns. Pelo contrário, principalmente no caso da Codevasf, cujos objetivos que orientaram a construção das cisternas tornaram-se bem distintos e até mesmo conflitantes no desenrolar da implementação do P1MC.

A descentralização constitucionalmente estabelecida da política de assistência social não foi por si só capaz de desenvolver as capacidades de gestão das prefeituras municipais na região de modo a operarem em bases técnico-administrativas alinhadas às institucionalidades participativas inerentes ao seu desenho. Isso evidencia um deficit de implementação e revela que o desenho institucional da descentralização e da participação social, traçado constitucionalmente, não criou maior espaço para conexões sinérgicas, conforme indicado por Evans (1995; 1996). 
A criatividade ficou por conta exclusivamente das organizações da sociedade civil. Estas foram capazes de desenvolver coerência organizacional por meio de interações alicerçadas em laços de confiança entre os agentes, possibilitado o acúmulo de capital social e o desenvolvimento de capacidade associativa para empreender a criação de um regime organizacional imaginativo como a ASA Brasil e a gestão social do P1MC.

Porém, essas novas dotações socioculturais não foram suficientes para reconfigurar todo o ambiente institucional, de modo que são substancialmente limitantes as interações daquelas organizações com as organizações públicas enraizadas na estrutura circundante da microrregião de Juazeiro. Para Evans (1993; 1995; 1996), o empreendedorismo institucional deve potencializar e promover arranjos apropriados que, por intermédio da sinergia entre o Estado e sociedade, propiciem a mudança dessas estruturas. Apesar de o empreendimento ter ficado limitado à dinâmica da sociedade civil, não propiciou uma maior abertura organizacional por parte das organizações estatais para criar sinergia institucional na transformação das relações e das estruturas locais existentes, ainda que a democratização do Estado brasileiro demandasse novos arranjos na formulação, implementação e coordenação das políticas públicas.

Disso resultou que o P1MC operasse fundamentalmente sobre as bases de coprodução, como define Ostrom (1996), dada a utilização de recursos complementares. Assim, impõe-se o desafio de envolver Estado e sociedade de modo sinérgico a fim de empreender e consolidar mudanças institucionais mais amplas nas estruturas circundantes do Semiárido brasileiro. Destarte, sugere-se que pesquisas futuras estejam orientadas ao estudo sobre o desenvolvimento das capacidades sinérgicas de Estado e sociedade naquilo que a criação de arranjos inovadores pode orientar sobre construção de políticas de convivência com o Semiárido e consolidação de mudança institucional na região. 


\section{REFERÊNCIAS}

ANDRADE, J. A.; CORDEIRO NETO, J. R.; VALADÃO, J. A. D. Associações sociotécnicas e práticas de gestão em desenvolvimento: analisando rastro por entre o traçado do P1MC. Cad. EBAPE.BR, v. 11, n. 2, p. 274-294, 2013.

ANDRADE, M. C. O Nordeste e a questão regional. 2. ed. São Paulo: Ática, 1993.

ARAÚJO, T. B. Ensaios sobre o desenvolvimento brasileiro: heranças e urgência. Rio de Janeiro: REVAN/FASE, 2000.

ASA. P1MC: um programa construído a muitas mãos. In: ASA. Construindo futuro e cidadania no Semiárido. Recife: 2011.

ASSIS, T. R. de P. Sociedade civil, Estado e políticas públicas: reflexão a partir do Programa Um Milhão de Cisternas Rurais (P1MC) no estado de Minas Gerais. 2006. Tese (Doutorado em Ciências Sociais em Agricultura, Desenvolvimento e Sociedade.) - CPDA/UFRRJ, Rio de Janeiro, 2006.

BARDIN, L. Análise de conteúdo. Lisboa: Edições 70, 2002.

BAUER, M. W.; AARTS, B. A construção do corpus: um princípio para a coleta de dados qualitativos. In: BAUER, M. W.; GASKELL, G. (Orgs). Pesquisa qualitativa com texto, imagem e som: um manual prático. Petrópolis, RJ: Vozes, 2002. 39-63 p.

BRASIL. Grupo de Trabalho Para o Desenvolvimento do Nordeste: uma política de desenvolvimento econômico do nordeste. Rio de Janeiro: Imprensa Nacional, 1959.

BRASIL. Tribunal de Contas da União. Relatório de avaliação de programa: Ação Construção de Cisternas para Armazenamento de Água. Brasília: TCU, 2006.

CAMPOS, A.; ALVES, A. M. O programa água para todos: ferramenta poderosa contra a pobreza. In: Ministério do Desenvolvimento Social - Brasil sem Miséria, 2014.

CAMPOS, J. N. B. Secas e políticas públicas no Semiárido: ideias, pensadores e períodos. Estudos Avançados, v. 28, n. 82, p. 65-88, 2014

CANO, W. Furtado: a questão regional e a agricultura itinerante no Brasil. Cadernos do Desenvolvimento, v. 5, n. 7, p. 23-51, 2010.

CARDOSO, F. H. Autoritarismo e democratização. Rio de Janeiro: Paz e Terra, 1975.

CARVALHO, J. O.; EGLER, C. A. G. Alternativas para o desenvolvimento do Nordeste Semiárido. Fortaleza: BNB, 2003.

CASTRO, J. Sete palmos de terra e um caixão: ensaio sobre o Nordeste, área explosiva. 2. Edição. São Paulo: Brasiliense, 1967.

CHACON, S. O Sertanejo e o caminho das águas: políticas públicas, modernidade e sustentabilidade no semi-árido. Fortaleza: BNB, 2005. (Série Teses e Dissertações. v. 8).

CORDEIRO NETO, J. R.; VALADÃO, J. A. D.; ANDRADE, J. A. Capital Social na Constituição e Operacionalização do P1MC: uma análise das dimensões desenvolvidas na microrregião de Juazeiro - BA. Revista Brasileira de Gestão e Desenvolvimento Regional, v. 10, n. 4, p. 46-69, 2014.

CÔRTES, S. V. Introdução: atores, mecanismos e dinâmicas participativas. In: CÔRTES, S. V. (Org.). Participação e saúde no Brasil. Rio de Janeiro: Editora Fiocruz, 2009. Introdução.
COSTA, F. L. Relações Estado-Sociedade no Brasil: representações para o uso de reformadores. DADOS - Revista de Ciências Sociais, v. 52, n. 2, p. 161-199, 2009.

CRESWELL, J. W. Qualitative inquiry and research design: choosing among five approaches. Thousand Oaks: Sage Publications, 2007.

DAHL, R. A. A moderna análise política. 2. ed. Rio de Janeiro: Lidador, 1970.

DINIZ, E. Em busca de um novo paradigma: a reforma do Estado no Brasil dos anos 90. São Paulo em Perspectiva, v. 10, n. 4, p. 13-26, 1996.

EASTON, D. A framework for political analisys. Englewood Cliffs: Prentice Hall, 1965.

EVANS, P. O Estado como problema e solução. Lua Nova, n. 28-29, São Paulo, 1993.

EVANS, P. Embedded autonomy: states and industrial transformation. Princeton, NJ: Princeton University Press, 1995.

EVANS, P. Government action, social capital and development: reviewing the evidence on synergy. World Development, v. 24, n. 6, p. 1073-1087, 1996

FARIA, C. A. P. Idéias, conhecimento e políticas públicas: um inventário sucinto das principais vertentes analíticas recentes. Revista Brasileira de Ciências Sociais, v. 18, n. 51, p. 21-29, 2003.

FERREIRA, A. Da invenção criadora do GTDN à reinvenção do futuro na década perdida. In: O Pensamento de Celso Furtado e o Nordeste hoje. Rio de Janeiro: Contraponto; Centro Internacional Celso Furtado de Políticas para o Desenvolvimento; Banco do Nordeste, 2009.

FLEURY, S. Politicas Sociales y Ciudadana. IDB Publications, 1999.

FLICK, U. Introdução à pesquisa qualitativa. Porto Alegre: Artmed, 2009.

GIDDENS, A. Agency, institution and time-space analysis. In: KNORRCETINA, K.; CICOUREL, A. (Eds.). Advances in social theory and methodology, toward an integration of micro and macro-sociologies. Boston: Routledge \& Kegan Paul, 1981. 161-174 p.

GODOY, A. S. Estudo de caso qualitativo. In: GODOI, C. K.; BANDEIRADE-MELO, R.; SILVA, A. B. (Org.). Pesquisa qualitativa em estudos organizacionais: paradigmas, estratégias e métodos. São Paulo: Saraiva, 2006

GOMIDE, A. A.; PIRES, R. R. C. Capacidades estatais e democracia: arranjos institucionais de políticas públicas. Brasília: IPEA, 2014.

GRANOVETTER, M. Ação econômica e estrutura social: o problema da imersão. In: MARTES, A. C. B. Redes e sociologia econômica. São Carlos: EdUFSCar, 2009.

JANN, W.; WEGRICH, K. Theories of the policy cycle. In: FISCHER, F.; MILLER, G. J.; SIDNEY, M. S. Handbook of public policy analysis. New York, USA: Taylor \& Francis, 2007. 43-62 p.

JEPERSON, R. L. Institutions, institutional effects, and institutionalism. In: POWELL, W. W.; DIMAGGIO, P. J. The new institutionalism in organizational analysis. Chicago, USA: The University of Chicago Press, 1991. 
JOVCHELOVITCH, S.; BAUER, M. Entrevista narrativa. In: BAUER, M. W.; GASKELL, G. (Org.). Pesquisa qualitativa com texto, imagem e som: um manual prático. Petrópolis, RJ: Vozes, 2002. 90-113 p.

KATO, J. Institutions and rationality: three varieties of neo-institutionalists. British Journal of Political Science, v. 26, n. 4, p. 553-582, 1996.

LASWELL, L. H. D. Politics: who gets what, when, how. Cleveland, USA: Meridian Books, 1958.

LATOUR, B. Jamais fomos modernos. São Paulo: Editora 34, 1994.

LATOUR, B. A esperança de pandora. São Paulo: Edusc, 2001.

LEVI, M. Social and unsocial capital: a review essay of Robert Putnam's Making Democracy Work. Politics \& Society, v. 24, n. 1, p. 45-55, 1996.

MALVEZZI, R. Semiárido: uma visão holística. Brasília: CONFEA, 2007.

MARQUES, E.C. Estado e redes sociais. Rio de Janeiro: Renavan/ Fapesp, 2000.

MDS. Ministério do Desenvolvimento Social. Programa Cisternas: Acesso à Água para Segurança Alimentar. Dez/2010. Impresso.

MEDEIROS, J. C. A.; SILVEIRA, S. M. B.; NEVES, R. S. Água e cidadania no Semiárido brasileiro: a experiência do P1MC da ASA Brasil. ANAIS... VIII Congresso Latino-americano de Sociologia Rural, Porto de Galinhas, Pernambuco, Brasil, 2010.

NUNES, E. A Gramática política no Brasil: clientelismo e insulamento burocrático. 3. ed. Rio de Janeiro: Zahar, 2003.
O’DONNELL, G. Democracia Delegativa? In: Novos Estudos. n. 31, São Paulo: CEBRAP, 1991. 25-40 p.

OSTROM, E. Crossing the great divide: coproduction, synergy, and development. World Development, v. 24, n. 6, p. 10731087, 1996.

PUTNAM, R. Comunidade e democracia: a experiência da Itália moderna. Rio de Janeiro: Editora FGV, 1996.

SILVA, R. M. A. da. Entre o combate à seca e a convivência com o Semi-Árido: transições paradigmáticas e sustentabilidade do desenvolvimento. 2006. Tese (Doutorado em Desenvolvimento Sustentável), UNB, Brasília, 2006.

SOUZA, C. Políticas públicas: uma revisão da literatura. Sociologias, v. 18, n. 16, p. 20-45, 2006.

STAKE, R. E. Qualitative case studies. In: DEZIN, N.; LINCOLN, Y. S. (Eds.). The sage handbook of qualitative research. London: Sage, 2005. 435-454 p.

TAPIA, J. R. B. Corporativismo societal no Brasil: uma transição incompleta? In: DAGNINO, E. (Org.). Os anos 90: política e sociedade no Brasil. São Paulo: Brasiliense, 1994. 65-77 p.

WOOLCOCK, M.; NARAYAN, D. Social capital: implications for development theory, research, and policy. The World Bank Research Observer, v. 15, n. 2, p. 225-249, 2000.

YIN, R. K. Estudo de caso: planejamento e métodos. Porto Alegre: Bookman, 2010.

Jackeline Amantino de Andrade

Doutora em Administração pela Universidade Federal do Rio Grande do Sul; Professora Associada da Universidade Federal de Pernambuco Departamento de Ciências Administrativas e do Programa de Pós-Graduação em Administração - DCA/PROPAD/CCSA/UFPE. E-mail: jackeline. amantino@gmail.com 